\title{
0764 Direct Detection of Actinomyces spp. from Infected Root Canals in a Chinese Population: $A$ Study Using PCR-based, Oligonucleotide-DNA Hybridization Technique
}

\author{
G. TANG, H.K. YIP, L.P. SAMARANAYAKE, and B.P.K. CHEUNG, The \\ University of Hong Kong, China
}

Objectives: The traditional methods of detection of Actinomyces spp. in infected root canals entail recovery and differentiation of bacterial phenotypes. However, the poor sensitivity of biochemical identification techniques has hampered the taxonomic differentiation of this genus. Hence we developed a sensitive and specific PCR-based oligonucleotide-DNA hybridization technique to detect Actinomyces spp. directly obtained from infected root canals. Methods: A total of 32 samples from 28 Chinese patients, with primary root canal infections aseptically exposed at the first patient visit were studied. Whole bacterial genomic DNA was isolated directly from paper point samples. The variable regions of $16 \mathrm{~S}$ ribosomal DNA of bacteria were amplified and labeled with digoxigenin for further hybridization and detection. A total of six oligonucleotide probes specific for A. bovis, A. gerencseriae, A. israelii, A. meyeri, A. naeslundii, A. odontolyticus and A. viscosus were used. Results: 16 of the 32 teeth were infected with one or more of Actinomyces species, and the prevalence rates of the examined species were: A. odontolyticus (31.3\%), A. meyeri (9.38\%), A. israelii

(6.25\%), A. naeslundii (6.25\%), A. gerencseriae (3.13\%), and A. viscosus (3.13\%); no A. bovis was detected in any of the canals. Furthermore, A. odontolyticus was isolated more frequently from root canals with caries or a history of caries $(\mathrm{P}=0.0496)$, and $\mathrm{A}$. naeslundii was significantly associated with traumatized teeth $(\mathrm{P}=0.0121)$. However, no significant correlation was found between Actinomyces spp. and clinical symptoms and signs, such as pain, swelling, percussion to tenderness, sinus and periapical radiolucency. Conclusion: Actinomyces spp. participate in root canal infections, and A. odontolyticus appears to be closely involved in endodontic infection either due to caries or opening of dentinal tubules during cavity preparation. (Supported by the RGC (10202943) and CRCG (10203286 and 10203775) in Hong Kong).

$\underline{\text { Seq \#88 - Oral Microbiology \& Immunology--Poster Discussion A }}$ 1:45 PM-3:45 PM, Thursday, 26 June 2003 Svenska Massan J1

Back to the Microbiology / Immunology and Infection Control Program Back to the 81st General Session of the International Association for Dental Research (June 25-28, 2003) 